\title{
IMPROVEMENT OF CARDIOVASCULAR FUNCTION HEALTH LEVEL BY REGULAR SPORTS
}

\author{
MELHORIA DO NIVELL DE SAÚDE DA FUNÇÃO CARDIOVASCULARPORMEIO DE \\ ESPORTES REGULARES
}

Original Article

ARTIGO ORIGINAL

Artículo Original

\section{MEJORA DEL NIVEL DE SALUDDE LA FUNCIÓN CARDIOVASCULAR MEDIANTE DEPORTES REGULARES.}

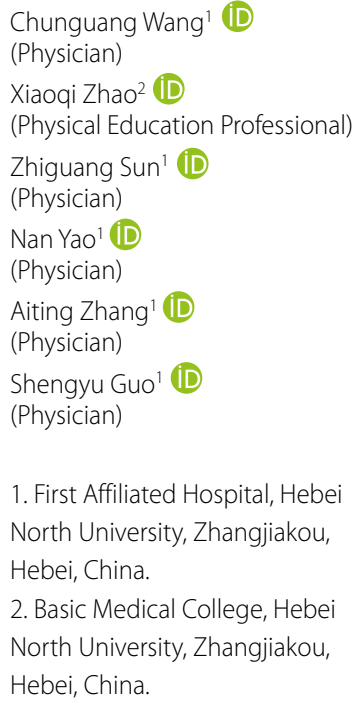

1. First Affiliated Hospital, Hebei North University, Zhangjiakou, Hebei, China.

2. Basic Medical College, Hebei North University, Zhangjiakou, Hebei, China.

\section{Correspondence:}

Xiaoqi Zhao

Basic Medical College, Hebei North University, Zhangjiakou, Hebei, 075000, China.

zxq8045217@163.com

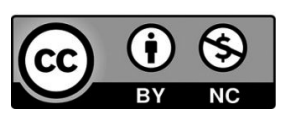

\begin{abstract}
Introduction: Regular physical activity helps improve cardiovascular and cerebrovascular skills. How to evaluate the nervous tension of the cardiovascular and cerebrovascular vessels through sports is a hot topic. Objective: The paper discusses the influence of regular participation in sports on people's cardiovascular function and blood-related indicators. Methods: We select 30 healthy older adults who regularly participate in sports, record their ECG changes, blood pressure, heart rate and other related cardiovascular function indicators, and analyze the blood function of the elderly. Detection of blood cell count (RBC), red blood cell volume (MCV) and hemoglobin ( $\mathrm{Hb})$, serum creatinine (Cr), blood glucose (BGS), triglycerides (TG), cholesterol (TC), low-density lipoprotein (LDL) and high-Density lipoprotein $(\mathrm{HDL})$ is measured. Results: Older adults who persist in exercise for a long time have better indicators than those who do not exercise. Conclusions: Appropriate aerobic exercise can reduce the stiffness of blood vessels in the elderly. Exercise can help the elderly increase heart rate variability and improve the heart's autonomic nerve function's blood indicators, and body mass. Level of evidence Il; Therapeutic studies - investigation of treatment results.
\end{abstract}

Keywords: Aged; Exercise; Cardiorespiratory Fitness; Cardiovascular Diseases.

\section{RESUMO}

Introdução: A atividade física regular ajuda a melhorar as habilidades cardiovasculares e cerebrovasculares. Como avaliar a tensão nervosa dos vasos cardiovasculares e cerebrovasculares por meio de esportes éum assunto quente. Objetivo: o artigo discute a influência da participação regular em esportes sobre a função cardiovascular das pessoas e indicadores relacionados ao sangue. Métodos: Selecionamos 30 idosos saudáveis que participam regularmente deesportes, registramos suas alterações no ECG, pressão arterial, frequência cardíaca e outros indicadores relacionados à função cardiovascular e analisamos a função sanguínea dos idosos. Detecção de contagem de células sanguíneas (RBC), volume de glóbulos vermelhos (MCV) e hemoglobina (Hb), creatinina sérica (Cr), glicose no sangue (BGS), triglicerídeos (TG), colesterol (TC), lipoproteína de baixa densidade (LDL) e a lipoproteína de alta densidade (HDL) é medida. Resultados: Idosos que persistem por muito tempo nos exercícios têm melhores indicadores do que aqueles que não praticam. Conclusão: O exercício aeróbio adequado pode reduzir a rigidez dos vasos sanguíneos em idosos. O exercício pode ajudar os idosos a aumentar a variabilidade da frequência cardíaca e melhorar os indicadores sanguíneos da função nervosa autonômica do coração e a massa corporal. Nível de evidência ll; Estudos terapêuticos - investigação dos resultados do tratamento.

Descritores: Idoso; Exercício Físico; Aptidão Cardiorrespiratória; Doenças Cardiovasculares.

\section{RESUMEN}

Introducción: La actividad fisica regular ayuda a mejorar las habilidades cardiovasculares y cerebrovasculares. Cómo evaluar la tensión nerviosa de los vasos cardiovasculares y cerebrovasculares a través del deporte es un tema candente. Objetivo: El artículo analiza la influencia de la participación regularen deportes sobre la función cardiovascular de las personas y los indicadores relacionados con la sangre. Métodos: Seleccionamos a 30 adultos mayores sanos que participan regularmente en deportes, registramos sus cambios en el ECG, presión arterial, frecuencia cardíacay otros indicadores relacionados con la función cardiovascular, y analizamos la función sanguínea de los ancianos. Detección del recuento de glóbulos rojos (RBC), volumen de glóbulos rojos (MCV) y hemoglobina (Hb), creatinina sérica (Cr), glucosa en sangre (BGS), triglicéridos (TG), colesterol (TC), lipoproteínas de baja densidad (LDL)) yse mide la lipoproteín a de alta densidad (HDL). Resultados: Los adultos mayores que persisten en el ejercicio durante mucho tiempo tienen mejores indicadores que los que no lo hacen. Conclusión: El ejercicio aeróbico adecuado puede reducir la rigidez de los vasos sanguíneos en los ancianos. El ejercicio puede ayudar a los ancianos a aumentar la variabilidad de la frecuencia cardíaca y mejorar los indicadores sanguíneos y la mas a corporal de la función nerviosa autónoma del corazón. Nivel de evidencia ll; Estudios terapéuticos: investigación de los resultados del tratamiento.

Descriptores: Anciano; Ejercicio Físico; Capacidad Cardiovascular; Enfermedades Cardiovasculares. 


\section{INTRODUCTION}

How to improve the level of altitude exercise and hypoxic exercise's physiological effects on the human body has been extensively studied internationally. Heart rate variability (HRV) is an important index to evaluate the autonomic nervous system's tension and balance and is an independent risk factor for cardiovascular disease. ' We use the blood oxygen and blood pressure changes and heart rate variability of the healthy elderly who have participated in sports for a long time in the middle and high-altitude areas of $2260 \mathrm{~m}-3200 \mathrm{~m}^{2}$

\section{METHOD}

\section{Object}

\section{Sports group}

From October 2018 to March 2019, 30 healthy older people from areas $\geq 2260 \mathrm{~m}$ received a physical examination, including 16 males and 14

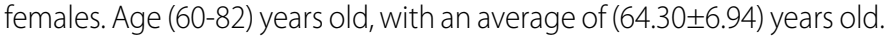

\section{The lack of exercise group}

During the same period, 30 healthy older adults were examined in our outpatient clinic, including 18 males and 12 females. Age (62-84) years old, average age $(64.96 \pm 10.84)$ years old.

\section{METHOD}

\section{Instruments and items}

Each batch of 6 subjects collected cubital venous blood in the early morning on an empty stomach, separated serum samples and stored them at $-20^{\circ} \mathrm{C}$ for testing. The two groups of people were measured: red blood cell count (RBC), red blood cell volume (MCV) and hemoglobin ( $\mathrm{Hb})$. Ethylenediaminetetraacetic acid disodium (EDTA-Na2) was used for anticoagulation, and it was determined by the Japanese East Asia Classification Hematology Analyzer. ${ }^{3}$ Use Hitachi-7170s automatic biochemical analyzer made in Japan to detect renal function creatinine ( $\mathrm{Cr}$ ), blood sugar (BGS) and blood lipids: Randox, UK provided triglycerides (TG), cholesterol (TC), low-density lipoprotein (LDL) and high-density lipoprotein (HDL), the kit.

\section{Determination of PWV/ABI}

We use the Japanese Colin VP-1000 automatic arteriosclerosis tester, at a room temperature of about $20^{\circ} \mathrm{C}$, the patient rests for 5 minutes to test, adopt a standard supine position, the limbs are tied with four sociometric blood pressure cuffs, synchronously record and analyze the report baPWV. Take the high value of baPWV on the left and right sides for statistical analysis. The calculation of $A B I$ adopts the method recommended by the American Heart Association (AHA). The unilateral $A B I$ calculation is the ratio of the systolic pressure of the lateral ankle artery (posterior tibial artery or dorsal foot artery) to the highest value of the bilateral brachial artery systolic pressure. ${ }^{4}$ Take the low value of $A B I$ on both sides for statistical analysis. Pulse pressure (PP) measurement.

\section{Methods of measuring blood pressure, heart rate and oxy- gen saturation during exercise}

We use the Marquette2000 exercise platform tester and the Bruce exercise program. The exercise time is $10 \mathrm{~min}$, the exercise speed is $3 \mathrm{~km} / \mathrm{h}$, and the slope is 10 degrees. It is measured at $5 \mathrm{~min}$ and $10 \mathrm{~min}$, respectively, and records are made. ${ }^{5}$ The same person measures the desktop sphygmomanometer and the American finger pulse meter (Inc) before exercise, the blood pressure, heart rate (HR) and oxygen saturation $(\mathrm{SaO} 2)$ at $5 \mathrm{~min}$ and $10 \mathrm{~min}$ during exercise. ${ }^{6}$

\section{Statistical processing}

The measurement data are expressed as mean \pm standard deviation, and we use SPSS10.0 statistical software package for analysis and processing. The comparison between groups was performed by t-test and $F$ test. For the splitting of random decision tree nodes, this article uses a splitting method that is different from the Gini value, which is an unbiased split based on conditional probability:

$$
M\left(A_{i}\right)=\frac{\left(\sum_{j=1}^{m_{i}} p\left(v_{i, j}\right)^{2} \sum_{i=1}^{c} p\left(y_{i} \mid v_{i, j}\right)^{2}\right)-\left(\sum_{j=1}^{m_{i}} p\left(v_{i, j}\right)^{2} \sum_{i=1}^{c} p\left(y_{i}\right)^{2}\right)}{\left(\sum_{i=1}^{c} p\left(v_{i, j}\right)^{2}\left(1-\sum_{i=1}^{c} p\left(y_{i}\right)^{2}\right)\right.}
$$

$m_{i}$ is the value of attribute $A_{i} ; p\left(v_{i, j}\right)$ is the probability that attributes $A_{i}$ is the value of $v_{j}$; c is the number of categories in the training sample; $p\left(y_{j} \mid v_{i, j}\right)$ is the probability that the class label $y_{j}$ is $v_{j}$ under the condition of the attribute $A_{i}$. We randomly shuffle the value of the h-th variable in the OOB sample. Obtain a new test sample $o o b_{h}$, and then use the $o o b_{h}$ sample to test the accuracy of the random forest and also obtain an accuracy rate $k_{h}$. Obtain the importance of the variable $M 1_{h}$ by the following formula

$M 1_{h}=\max \left\{0 ; e_{h}-k\right\}$

Therefore, the final variable importance output is:

$$
M 1=\left[\begin{array}{r}
M 1_{1} \\
\mathrm{M} \\
M 1_{m}
\end{array}\right]
$$

Where $m$ is the attribute value of the training sample, it can be seen from formula (4) that the importance of variables is calculated as the correlation of all variables to all categories. If we want to obtain the variables most relevant to category i, we cannot obtain them.

$$
M 2_{h}^{k}=\max \left\{0 ; \operatorname{avs}\left[m g(y, X)-m g_{h}(y, x)\right]\right\}
$$

Among them, mg $(y, x)$ is the interval function. We use $M 1^{* k}=M 1_{h}^{k}+M 2_{h}^{k}$ as the output of the importance of the last variable. Its form is as (5)

$M 1^{*}=\left[\begin{array}{cc}M 1_{1}^{{ }_{1}} \mathrm{~L} & M 1_{1}^{*_{1}} \\ \mathrm{M} \mathrm{L} & \mathrm{M} \\ M 1^{*}{ }_{h} \mathrm{~L} & M 1^{* *}\end{array}\right]$

Among them, $\mathrm{k}$ is the number of sample categories, that is, $\mathrm{k}=1_{\text {" }} \mathrm{c}$. It can be seen from the output (5) that the importance of the variable gives the value of the variable related to each category. This is very helpful for fault diagnosis.

\section{RESULTS}

The effect of regular exercise on blood indicators related to cardiovascular disease in the elderly at high altitude

The number of RBCs in healthy older people in plateau areas who persisted in exercising for a long time increased significantly $(P<0.05)$. Still, MCV and $\mathrm{Hb}$ had no significant changes than the elderly in the lack of exercise. The levels of BGS, TC, and LDL in the exercise group were significantly reduced $(P<0.05)$, but there were no significant differences in $\mathrm{Cr}, \mathrm{TG}$, and $\mathrm{HDL}$ levels. (Table 1)

\section{The effect of regular exercise on the vascular function of the elderly in plateau areas}

Compared with the exercise group and the lack of exercise group, the weight, body mass index, and pulse pressure were statistically significant 
$(P<0.05)$, and the baPWV and $A B I$ of the arteriosclerosis index were significantly different $(P<0.01)$; while the age, gender and height were significantly different. (Table 2)

\section{The effect of exercise on the heart rate variability of healthy older adults at altitude}

Through 24-hour HRV analysis in this group, it was found that the indicators of SDNN, RMSSD and PNN50 of the elderly in the regular exercise group were higher than those in the lack of exercise group. (Table 3)

\section{Observation of changes in blood pressure, heart rate and oxygen saturation during exercise}

We found that in the resting state, the systolic blood pressure, diastolic blood pressure and heart rate of the elderly who exercise regularly are lower than those of the inactive elderly. The systolic blood pressure of the exercise group increased with the increase of exercise volume than at rest. The diastolic blood pressure first decreased and then increased with the increase of exercise volume? (Table 4)

Table 1. Comparison of cardiovascular-related blood indicators between the elderly exercise group and the lack of exercise group.

\begin{tabular}{c|c|c|c}
\hline & Sports group & Lack of exercise group & $\mathbf{P}$ \\
\hline Number of cases & 30 & 30 & \\
\hline $\mathrm{RBC}(1012 / \mathrm{L})$ & $4.88 \pm 0.59$ & $4.45 \pm 0.98$ & $<0.05$ \\
\hline $\mathrm{MCV}(\mathrm{FL})$ & $95.90 \pm 4.95$ & $96.88 \pm 5.20$ & $>0.05$ \\
\hline $\mathrm{Hb}(\mathrm{g} / \mathrm{L})$ & $148.31 \pm 9.07$ & $149.7 \pm 8.23$ & $>0.05$ \\
\hline $\mathrm{Cr}(\mu \mathrm{mol} / \mathrm{L})$ & $81.82 \pm 17.00$ & $83.08 \pm 14.06$ & $>0.05$ \\
\hline
\end{tabular}

Table 2. Comparison of arterial stiffness indexes between the elderly exercise group and the lack of exercise group.

\begin{tabular}{c|c|c|c}
\hline Group & Sports group & Lack of exercise group & P \\
\hline Number of cases & 30 & 30 & \\
\hline gender & $16 / 14$ & $12 / 18$ & \\
\hline Age $(\mathrm{y})$ & $64.30 \pm 11.91$ & $64.96 \pm 10.84$ & $>0.05$ \\
\hline Weight $(\mathrm{kg})$ & $64.97 \pm 10.62$ & $70.15 \pm 12.13$ & $<0.05$ \\
\hline Height $(\mathrm{cm})$ & $165.66 \pm 7.55$ & $166.14 \pm 8.17$ & $>0.05$ \\
\hline Body mass index $\left(\mathrm{kg} / \mathrm{m}^{2}\right)$ & $24.34 \pm 3.27$ & $29.66 \pm 3.28$ & $<0.05$ \\
\hline Pulse pressure $(\mathrm{mmHg})$ & $45.17 \pm 10.771$ & $49.13 \pm 7.471$ & $<0.05$ \\
\hline baPWV $(\mathrm{m} / \mathrm{s})$ & $409.59 \pm 202.14$ & $921.63 \pm 392.77$ & $<0.01$ \\
\hline $\mathrm{ABI}$ & $1.13 \pm 0.15$ & $1.01 \pm 0.13$ & $<0.01$ \\
\hline
\end{tabular}

Table 3. Comparison of 24-hour HRV domain between elderly exercise group and lack of exercise group.

\begin{tabular}{c|c|c|c}
\hline Group & Sports group & Lack of exercise group & $\mathbf{P}$ \\
\hline Number of cases & $\mathbf{3 0}$ & $\mathbf{3 0}$ & \\
\hline SDNN & $133.55 \pm 16.94$ & $115.67 \pm 14.51$ & $<0.01$ \\
\hline SDANN & $116.81 \pm 20.85$ & $115.83 \pm 13.55$ & $>0.05$ \\
\hline SDNNindex & $52.31 \pm 16.29$ & $48.33 \pm 15.05$ & $>0.05$ \\
\hline RMSSD & $30.61 \pm 12.03$ & $20.52 \pm 14.44$ & $<0.01$ \\
\hline PNN50 & $11.20 \pm 9.38$ & $6.46 \pm 7.23$ & $<0.05$ \\
\hline
\end{tabular}

Table 4. Comparison of blood pressure, heart rate and oxygen saturation between the two groups before, during and after exercise.

\begin{tabular}{c|c|c|c|c|c}
\hline \multicolumn{2}{c|}{ Index } & $\begin{array}{c}\text { Systolic } \\
\text { blood } \\
\text { pressure } \\
\text { (mmHg) }\end{array}$ & $\begin{array}{c}\text { Diastolic } \\
\text { blood } \\
\text { pressure } \\
(\mathbf{m m H g})\end{array}$ & $\begin{array}{c}\text { Heart rate } \\
\left(\mathbf{m i n}^{-1}\right)\end{array}$ & $\begin{array}{c}\text { Oxygen } \\
\text { saturation (\%) }\end{array}$ \\
\hline \multirow{2}{*}{ Number of cases } & 30 & 30 & 30 & 30 \\
\hline \multirow{2}{*}{$\begin{array}{c}\text { Sports } \\
\text { group }\end{array}$} & Euiet & $123.50 \pm 16.94$ & $76.67 \pm 9.51$ & $67.60 \pm 10.33$ & $94.04 \pm 2.56$ \\
\cline { 2 - 6 } & Exercise $5 \mathrm{~min}$ & $136.81 \pm 20.85$ & $73.33 \pm 8.05$ & $109.77 \pm 15.41$ & $85.60 \pm 9.31$ \\
\hline \multirow{2}{*}{$\begin{array}{c}\text { Lack of } \\
\text { exercise } \\
\text { group }\end{array}$} & Exercise $5 \mathrm{~min}$ & $144.70 \pm 15.85$ & $94.00 \pm 10.53$ & $119.89 \pm 13.51$ & $83.11 \pm 7.85$ \\
\cline { 2 - 6 } & Exercise 10min & $139.00 \pm 17.74$ & $99.39 \pm 8.47$ & $104.21 \pm 15.00$ & $84.17 \pm 4.98$ \\
\hline
\end{tabular}

\section{DISCUSSION}

\section{The effect of regular exercise on the blood indicators of healthy older adults at altitude}

Jogging, brisk walking, Tai Chi and mountain climbing and other exercises are moderate in intensity. The energy consumed is mainly from the oxidation and decomposition of fat and sugar. They are aerobic exercises that can enhance physical fitness and prevent obesity and disease. Long-term living in the plateau has a very complex reaction to the body. Human body functions and exercise capabilities will be affected to varying degrees and are different from those in the plains. Studies have reported that aerobic metabolism improvement by altitude training mainly occurs in red blood cells, enzymes, maximum oxygen uptake, lactic acid tolerance, etc. The combined effects of the above are conducive to thoroughly stimulating and tapping the body's potential. High altitude hypoxia can stimulate the red blood cells of the kidneys. This study found that the number of RBCs in the elderly who insisted on aerobic exercise for a long time in the plateau area increased significantly. Still, MCV and Hb did not change significantly. ${ }^{8}$ This may be the effect of the chronic hypoxia environment and the dual stimulation of exercise and hypoxia on the red blood cell production of the elderly in the plateau area.

\section{The impact of exercise on HRV of healthy older adults at an altitude}

HRV refers to the phenomenon that the sinus heart rate changes periodically within a certain period. It is an important indicator that quantitatively reflects the sympathetic nerve's tension and balance and the vague nerve. It is a valuable indicator for the autonomic nerve to regulate the heart. It has high sensitivity. The advantages of non-invasiveness, etc., are widely used and studied in clinical medicine and aviation medicine.

\section{Discussion on changes in blood pressure, heart rate and oxygen saturation during exercise}

Some analysis confirmed that mild to moderate aerobic exercise training reduced systolic blood pressure and diastolic blood pressure by $2 \%$ and $1 \%$, respectively. Foreign studies have shown that exercise training helps change the risk factors of coronary heart disease, including the resting blood pressure of hypertensive patients. The results show that the systolic blood pressure of healthy older people in plateau areas who exercise for a long time increases with exercise volume. The diastolic blood pressure first decreases with the increase in exercise volume. 


\section{CONCLUSION}

Regular participation in moderate-intensity exercises for the elderly in high altitude areas can improve the body's blood indicators, reduce vascular stiffness and increase heart rate variability, and enhance the blood and oxygen supply of the heart and blood vessels to various organs and tissues, which is helpful for fitness or prevention of plateaus. Regional cardiovascular disease is of great significance. ratedeceleration runs in the early warning of sudden cardiac death in patients with acute myocardial infarction.(NO:20190873). Youth Fund Project of Hebei Education Department: Evaluation of heart rate deceleration force on cardiac vagus function and its high risk warning in elderly patients with coronary heart disease. (NO:QN2016263).

\section{ACKNOWLEDGMENTS}

Medical science research project plan of hebei province: heart

All authors declare no potential conflict of interest related to this article

AUTHORS' CONTRIBUTIONS: Each author made significant individual contributions to this manuscript. Chunguang Wang and Shengyu Guo: writing and performing surgeries; Xiaogi Zhao: data analysis; Zhiguang Sun: performing surgeries; Nan Yao and Aiting Zhang: article review and intellectual concept of the article.

\section{REFERENCES}

1. Andrzejaczek S, Gleiss AC, Pattiaratchi CB, Meekan MG. Patterns and drivers of vertical movements of the large fishes of the epipelagic. Rev Fish Biol Fish. 2019 [cited 2021 Jun 11];29(2):335-54. Available from: https://researchrepository.murdoch.edu.au/id/eprint/45865/

2. Xie H, Zhang M, Huo C, Xu G, Li Z, Fan Y. Tai Chi Chuan exercise related change in brain function as assessed by functional near-infrared spectroscopy. Sci Rep. 2019;9(1):13198.

3. Ruíz-Moreno C, Lara B, Brito de Souza D, Gutiérrez-Hellín J, Romero-Moraleda B, Cuéllar-Rayo Á, Del Coso J. Acute caffeine intake increases muscle oxygen saturation during a maximal incremental exercise test. Br J Clin Pharmacol. 2020;86(5):861-7.

4. Andreyeva AY, Soldatov AA, Krivchenko Al, Mindukshev IV, Gambaryan S. Hemoglobin deoxygenation and methemoglobinemia prevent regulatory volume decrease in crucian carp
(Carassius carassius) red blood cells. Fish Physiol Biochem. 2019;45(6):1933-1940.

5. Wu S, Wang N, Li J, Wang G, Seto SW, Chang D, et al. Ligustilide ameliorates the permeability of the blood-brain barrier model in vitro during oxygen-glucose deprivation injury through HIF/VEGF pathway. J Cardiovasc Pharmacol. 2019;73(5):316-25.

6. Gao C, Lin Z, Wang D, Wu Z, Xie H, He Q. Red blood cell-mimicking micromotor for active photodynamic cancer therapy. ACS Appl Mater Interfaces. 2019;11(26):23392-23400.

7. Alvares TS, Oliveira GV, Soares R, Murias JM. Near-infrared spectroscopy-derived total haemoglobin as an indicator of changes in muscle blood flow during exercise-induced hyperaemia.J Sports $S c i .2020 ; 38(7): 751-8$

8. Qiu Y, Myers DR, Lam WA. The biophysics and mechanics of blood from a materials perspective. Nat Rev Mater. 2019;4(5):294-311. 